\title{
Nutritional Status and Food Consumption Pattern of Tribal Farm Women of Sabarkantha
}

\author{
Preeti H. Dave $^{1 *}$, J.J. Mistry ${ }^{2}$ and M.K. Chaudhary ${ }^{3}$ \\ ${ }^{1}$ Food and Nutrition, ${ }^{2}$ Extension Education, ${ }^{3}$ Agriculture Statistics, Sardarkrushinagar \\ Dantiwada Agricultural University, S.K.Nagar, Banaskantha, Gujarat, India \\ *Corresponding author:
}

\section{A B S T R A C T}

\section{Keywords \\ Tribal farm women, Nutritional status, Food consumption pattern \\ Article Info \\ Accepted: \\ 18 February 2019 \\ Available Online: \\ 10 March 2019}

Tribal women play multiple roles in a family, primarily as mothers and housekeepers and also equally important roles as wage earners and agricultural producers. Tribal people are amongst the poorest population and experiencing extreme levels of health deprivation. Tribal follows very distinct dietary pattern and mainly rely upon locally available crops. Tribal women in India are at a great disadvantage due to illiteracy and ignorance. The present study was conducted in Khedbrahma and Poshina taluka of Sabarkantha district of Gujarat. To check the nutritional status of tribal farm women, BMI was measured and dietary assessment was done using food frequency method. It was observed that tribal farm women were coming from poor socio-economic background, most of them were illiterate, their income was less and nutritional status was poor. Their average height, weight and BMI was lower than reference Indian women. Their food consumption pattern was not appropriate and frequency of consuming nutritious foods.

\section{Introduction}

India is a home to tribal population (Agrawal, 2013). Tribal women play multiple roles in a family, primarily as mothers and housekeepers and also equally important roles as wage earners, agricultural producers, nutrition providers etc. They are instrumental in the acquisition of food, its preparation, storage and distribution. However, very often they are subjected to malnutrition and form a group highly vulnerable to morbidity and mortality. Rao et al., (1994 and 1996) noted that scheduled Tribe people constitute about $8 \%$ of the total population in India, with varying proportions in different States. They live in unique physical, socio-economic and cultural environment, isolated from general population. In view of their habitat and food habits, they form a distinct group compared to other populations. Their food intake is influenced by vagaries of nature, with large seasonal variations, depending upon availability of agricultural and forest produce. Several studies have documented a close relationship between the tribal ecosystem and their nutritional status. Sabrkantha district of Gujarat has tribal population. In the year 2006, 
the Ministry of Panchayati Raj considered Sabarkantha as one of the country's 250 most backward districts (out of a total of 640). Six districts of Gujarat are receiving funds from the Backward Regions Grant Fund Programme (BRGF) and Sabarkantha is one of them (Anonymous, 2009).

Tribal follows very distinct dietary pattern and mainly rely upon locally available crops. Tribal people are amongst the poorest population and experiencing extreme levels of health deprivation. Researchers have found that tribal women in India are at a great disadvantage due to illiteracy and ignorance. Tribal women are malnourished and their dietary energy intake is not adequate to compensate their heavy physical workload (Maiti et al., 2005). The present study was carried out to assess the nutritional status and food consumption pattern of tribal farm women of Sabarkantha district.

\section{Materials and Methods}

The present study was conducted in Sabarkantha district of Gujarat. Two tribal taluka of Sabarkantha district viz; Khedbrahma and Poshina were selected purposively for the study. Five villages from these two selected tribal taluka and thus total ten villages were selected randomly for the study. Total hundred tribal farm women were selected for present study. The data were collected by personal interview method. Dietary assessment was done using food frequency method. Anthropometric measurements were taken by using weighing scale, anthropometric rod and fibre glass tape. The cut off levels of the Body Mass Index as per Anonymous (2003) were used to classify subjects as malnourished, normal and obese. Body mass index (BMI) was calculated using anthropometric measurement (weight and height) and calculated by the formula given below:

$$
\mathrm{BMI}=\quad \frac{\text { Weight }(\mathrm{kg})}{\text { Height }(\mathrm{m})^{2}}
$$

\section{Results and Discussion}

Information regarding socio-economic background of tribal farm women were gathered and presented as below.

The data presented in Table 1 shows that majority of tribal farm women belonged to young and middle age group.

It can be seen from Table 2 that majority of tribal farm women were illiterate and overall education level was poor. Kupputhai and Mallika (1993) also noted that tribal women in India are at a great disadvantage due to illiteracy and ignorance.

Annual income of majority of tribal farm women was recorded very low. Dave et al., (2016) reported lower socio-economic condition of tribal families of Sabrkantha district (Table 3).

Table 4 depicts the data of anthropometric measurements. Height, weight and BMI are important indicators of nutritional status of the individual. It depicts that majority $(66 \%)$ of the tribal farm women had height in range of $150-165 \mathrm{~cm}$. But it also noticeable that little more than one fourth $(31 \%)$ tribal farm women were recorded having height less than $150 \mathrm{~cm}$. Only half $(53 \%)$ of the tribal farm women were showed BMI in acceptable range. Large numbers of tribal farm women (42\%) were found to be underweight. Agrawal (2013) carried out a study on tribal women of Orissa and reported that they were deprived in important aspects of health and nutrition. They studied that tribal women as compared with non tribal women were 2.3 times more illiterate, 1.3 times more likely to be underweight and anemic and were 4 times more likely to never/occasionally consume 
milk /curd or pulse/beans, 1.6 times more underweight.

Indian reference woman is between 18-29 years of age, non-pregnant non- lactating (NPNL) and weighs $55 \mathrm{~kg}$ with a height of $1.61 \mathrm{~m}$ and a BMI of 21.2, is free from disease and physically fit for active work; on each working day she is engaged in 8 hours of occupation which usually involves moderate activity, while when not at work she spends 8 hours in bed, 4-6 hours in sitting and moving about, 2 hours in walking and in active recreation or household duties (Anonymous, 2009). From the Table 5 it can be said that average height, weight and BMI was found lower than reference Indian women. Dave et al., (2016), conducted a study amongst tribal children of Sabarkantha and reported varying degree of malnutrition amongst children.

\section{Food consumption pattern}

Table 6 shows food consumption pattern of the tribal women. It was observed that tribal farm women consume maize followed by wheat and rice as the major cereals. Pulses and dals were taken twice a week while vegetables on daily bases. While taking personal interview of the tribal farm women it was found that though tribal farm women were utilizing locally available vegetables and pulse but their cooking method was not appropriate.

Vegetables were cut into large amount of water and then water was drained off which might result into leaching and loss of valuable vitamins and antioxidants. Open pan cooking of vegetables, pulses and dals was a regular practice instead of using presser cooker. These may lead to prolonged cooking time and considerable loss of heat liable and water soluble vitamins. Pulses and dals should be soaked before cooking and then pressure cooked to inactivate antinutrients and anti proteins of pulses, but this ideal practice was not followed. Use of nutritious and cheap minor millets was found to be very limited. Rao et al., (2006) studied tribal of nine different states of India and reported the similar findings.

Table.1 Distribution of the tribal farm women according to their age

\begin{tabular}{|c|c|c|c|}
\hline Sr. No & \multicolumn{1}{|c}{ Categories } & Frequency & Per cent \\
\hline $\mathbf{1}$ & Young (Up to 35 years ) & 44 & $\mathbf{4 4 . 0 0}$ \\
\hline $\mathbf{2}$ & Middle (35 to 50 years) & 45 & $\mathbf{4 5 . 0 0}$ \\
\hline $\mathbf{3}$ & Old (above 50 years) & 11 & $\mathbf{1 1 . 0 0}$ \\
\hline & Total & $\mathbf{1 0 0}$ & $\mathbf{1 0 0 . 0 0}$ \\
\hline
\end{tabular}

Table.2 Distribution of the tribal farm women according to their level of education

\begin{tabular}{|c|l|c|r|}
\hline Sr. No. & \multicolumn{1}{|c}{ Education } & Frequency & Per cent \\
\hline $\mathbf{1}$ & Illiterate & 74 & $\mathbf{7 4 . 0 0}$ \\
\hline $\mathbf{2}$ & Primary education (1-7 Std.) & 12 & $\mathbf{1 2 . 0 0}$ \\
\hline $\mathbf{3}$ & Secondary education (8-10 Std.) & 06 & $\mathbf{6 . 0 0}$ \\
\hline $\mathbf{4}$ & Higher secondary education (11-12 Std.) & 08 & $\mathbf{8 . 0 0}$ \\
\hline & Total & $\mathbf{1 0 0}$ & $\mathbf{1 0 0 . 0 0}$ \\
\hline
\end{tabular}


Table.3 Distribution of the tribal farm women according to their annual income

\begin{tabular}{|c|c|c|c|}
\hline Sr. No & Annual income & Frequency & Per cent \\
\hline 1 & Up to Rs. 25000 & 59 & 59 \\
\hline 2 & Rs. 25001 to Rs. 50000 & 27 & 27 \\
\hline 3 & Rs. 50001 to Rs. 75000 & 07 & 07 \\
\hline 4 & Rs. 75001 to Rs. 100000 & 05 & 05 \\
\hline 5 & Above Rs. 100000 & 02 & 02 \\
\hline \multicolumn{2}{|r|}{ Total } & 100 & 100.00 \\
\hline
\end{tabular}

Table.4 Distribution of the tribal farm women according to their Anthropometric Measurements

\begin{tabular}{|c|c|c|c|}
\hline Sr. No. & Anthropometric Measurements & Frequency & Per cent \\
\hline \multirow[t]{4}{*}{1} & Height $(\mathrm{cm})$ & & \\
\hline & $<150$ & 31 & 31.00 \\
\hline & $150-165$ & 66 & 66.00 \\
\hline & $>165$ & 03 & 03.00 \\
\hline \multirow[t]{5}{*}{2} & Weight $(\mathrm{Kg})$ & & \\
\hline & $<40$ & 16 & 16.00 \\
\hline & $40-50$ & 58 & 58.00 \\
\hline & $51-55$ & 14 & 14.00 \\
\hline & $>55$ & 12 & 12.00 \\
\hline \multirow[t]{5}{*}{3} & BMI & & \\
\hline & Underweight $(<18.50)$ & 42 & 42.00 \\
\hline & Acceptable (18.50-24.99) & 53 & 53.00 \\
\hline & Overweight (25.00-29.99) & 4 & 04.00 \\
\hline & Obese $(30-40)$ & 1 & 01.00 \\
\hline
\end{tabular}

Table.5 Comparison of anthropometric parameters of tribal farm women

\begin{tabular}{|c|l|c|}
\hline \multicolumn{2}{|c|}{ Anthropometric measurements } \\
\hline 1 & \multicolumn{2}{|c|}{ Height $(\mathrm{cm})$} \\
\hline & $\begin{array}{l}\text { Mean height of the tribal farm women } \\
\text { Reference height }\end{array}$ & $152.75 \pm \mathbf{5 . 8 9}$ \\
\hline $\mathbf{2}$ & Weight $(\mathrm{kg})$ & $\mathbf{1 . 6 1}$ meter $(\mathbf{1 6 1} \mathrm{cm})$ \\
\hline & Mean height of the tribal farm women & $\mathbf{4 6 . 4 1 \pm 7 . 3 4}$ \\
\hline $\mathbf{3}$ & Reference weight & $\mathbf{5 5}$ \\
\hline & BMI & $\mathbf{1 9 . 8 7 \pm 2 . 8 4}$ \\
\hline & Mean BMI of the tribal farm women & $\mathbf{2 1 . 2}$ \\
\hline
\end{tabular}


Table.6 Distribution of the tribal farm women according to their frequency of food consumption

\begin{tabular}{|c|c|c|c|c|c|c|c|}
\hline \multirow{3}{*}{$\begin{array}{l}\text { Sr. } \\
\text { No. }\end{array}$} & \multirow{3}{*}{ Food products } & \multirow{3}{*}{$\begin{array}{c}\text { Daily } \\
\%\end{array}$} & \multirow{3}{*}{$\begin{array}{c}\text { Twice a } \\
\text { week }\end{array}$} & \multirow{3}{*}{$\begin{array}{c}\begin{array}{c}\text { Once } \\
\text { a week }\end{array} \\
\%\end{array}$} & \multirow{3}{*}{$\begin{array}{c}\text { Monthly } \\
\%\end{array}$} & \\
\hline & & & & & & $\begin{array}{c}\text { Occasionally or } \\
\text { seasonal }\end{array}$ & Never \\
\hline & & & & & & $\%$ & $\%$ \\
\hline \multicolumn{8}{|c|}{ Cereals : } \\
\hline 1 & Rice & 14 & 14 & 24 & 35 & 4 & 9 \\
\hline 2 & Wheat & 12 & 24 & 37 & 15 & 0 & 12 \\
\hline 3 & Bajra & 8 & 8 & 10 & 16 & 10 & 48 \\
\hline 4 & Maize & 67 & 30 & 2 & 0 & 0 & 1 \\
\hline 5 & Jowar and other millets & 0 & 0 & 0 & 0 & 0 & 100 \\
\hline \multicolumn{8}{|c|}{ Pulses and legumes : } \\
\hline 1 & Pigeon pea & 11 & 7 & 17 & 30 & 10 & 25 \\
\hline 2 & Bangle gram & 0 & 4 & 4 & 11 & 3 & 78 \\
\hline 3 & Urad / Black gram & 6 & 12 & 22 & 30 & 5 & 25 \\
\hline 4 & Peas & 1 & 10 & 25 & 28 & 9 & 27 \\
\hline 5 & Green gram & 1 & 23 & 25 & 28 & 2 & 21 \\
\hline 6 & Soybean & 0 & 2 & 3 & 1 & 7 & 87 \\
\hline 7 & Pigeon pea (dal) & 11 & 27 & 33 & 23 & 4 & 2 \\
\hline 8 & Bangle Gram (dal) & 3 & 7 & 20 & 12 & 15 & 43 \\
\hline 9 & Black gram (dal) & 5 & 26 & 32 & 29 & 5 & 3 \\
\hline 10 & Green gram (dal) & 13 & 25 & 27 & 25 & 7 & 3 \\
\hline 11 & Any other (Pl specify) & - & - & - & - & - & - \\
\hline \multicolumn{8}{|c|}{ Green leafy vegetables : } \\
\hline 1 & Amaranth & 0 & 0 & 2 & 11 & 12 & 75 \\
\hline 2 & Spinach & 0 & 17 & 19 & 32 & 17 & 15 \\
\hline 3 & Fenugreek leaves & 1 & 23 & 27 & 29 & 13 & 7 \\
\hline 4 & Drumstick leaves & 0 & 7 & 13 & 7 & 4 & 69 \\
\hline 5 & Cabbage & 0 & 12 & 33 & 25 & 20 & 10 \\
\hline 6 & Cauliflower (Green) & 7 & 16 & 29 & 17 & 17 & 14 \\
\hline 7 & Coriander leaves & 28 & 46 & 11 & 4 & 5 & 6 \\
\hline 8 & Radish leaves & 0 & 25 & 20 & 15 & 26 & 14 \\
\hline 9 & Curry leaves & 15 & 20 & 54 & 8 & 0 & 3 \\
\hline 10 & Any other (Pl specify) & - & - & - & - & - & - \\
\hline \multicolumn{8}{|c|}{ Other vegetables : } \\
\hline 1 & Bottle gourd & 1 & 8 & 23 & 28 & 15 & 25 \\
\hline 2 & Brinjal & 4 & 16 & 21 & 25 & 9 & 25 \\
\hline 3 & Cauliflower & 2 & 17 & 29 & 26 & 16 & 10 \\
\hline 4 & Cucumber & 2 & 4 & 17 & 11 & 24 & 42 \\
\hline 5 & Ladies finger & 2 & 6 & 24 & 27 & 20 & 21 \\
\hline 6 & Tomato & 13 & 23 & 32 & 15 & 15 & 2 \\
\hline 7 & Cluster bean & 0 & 15 & 50 & 10 & 5 & 20 \\
\hline 8 & Bitter gourd & 1 & 6 & 32 & 25 & 27 & 9 \\
\hline 9 & Double bean & 0 & 15 & 43 & 14 & 26 & 2 \\
\hline 10 & Ridge gourd & 0 & 25 & 56 & 2 & 7 & 10 \\
\hline 11 & Kankoda & 7 & 18 & 19 & 6 & 49 & 1 \\
\hline 12 & Any other (Pl specify) & - & - & - & - & - & - \\
\hline \multicolumn{8}{|c|}{ Roots and Tubers : } \\
\hline 1 & Beet root & 0 & 2 & 2 & 0 & 31 & 65 \\
\hline 2 & Carrot & 4 & 13 & 17 & 16 & 45 & 5 \\
\hline 3 & Ginger & 32 & 16 & 6 & 9 & 18 & 19 \\
\hline 4 & Onion & 9 & 45 & 29 & 12 & 5 & $\mathbf{0}$ \\
\hline 5 & Potato & 6 & 27 & 38 & 14 & 8 & 7 \\
\hline 6 & Radish & 2 & 7 & 16 & 5 & 50 & 20 \\
\hline 7 & Sweet potato & 0 & 1 & 12 & 22 & 42 & 23 \\
\hline 8 & Any other (PI specify) & - & - & - & - & - & - \\
\hline
\end{tabular}


Table.7 Distribution of the tribal farm women according to their food habit

\begin{tabular}{|c|lc|c|c|}
\hline \multicolumn{1}{|c}{ Food habit } & \multicolumn{2}{c|}{$(\mathrm{n}=100)$} \\
\hline Sr. No. & & Frequency & Per cent \\
\hline $\mathbf{1}$ & Vegetarian & & 44 & $\mathbf{4 4 . 0 0}$ \\
\hline $\mathbf{2}$ & Non- vegetarian & & 56 & $\mathbf{5 6 . 0 0}$ \\
\hline & & Total & $\mathbf{1 0 0}$ & $\mathbf{1 0 0 . 0 0}$ \\
\hline
\end{tabular}

Table.8 Daily diet pattern of the tribal farm women

\begin{tabular}{|c|l|l|}
\hline \multicolumn{2}{|c|}{ Time } & \multicolumn{1}{c|}{ Meal pattern } \\
\hline Sr. No. & \multicolumn{1}{|c|}{ Tea (with or without milk) + wheat / maize roti (occasionally) } \\
\hline $\mathbf{1}$ & Break fast & Maize/ wheat roti + vegetable (green leafy and potato) / dal/pulses \\
\hline $\mathbf{2}$ & Lunch & Tea (with or without milk) \\
\hline $\mathbf{3}$ & Evening time & Maize/ wheat roti + khichari + green leafy vegetable or dal-bati \\
\hline $\mathbf{4}$ & Dinner & None \\
\hline $\mathbf{5}$ & Bed time & \\
\hline
\end{tabular}

They reported that the mean intake of all the foodstuffs, especially the income elastic foods such as pulses, milk and milk products, oils and fats and sugar \& jaggery were lower than the recommended levels of ICMR. About $42 \%$ of adolescent girls were undernourished $(<5$ th BMI age percentiles of NHANES).

Both vegetarian and non vegetarian food habits were prevailing among the tribal farm women (Table 7).

Table 8 shows daily diet pattern of the tribal farm women. It was observed that breakfast was not regularly consumed and skipped frequently. If milking animals are there than only tea with milk was consumed otherwise tea without milk was consumed. Both vegetables and dal/pulses were not consumed together in a single meal but they were consumed optional. Evening time snakes were not consumes. Looking to this it was found that balanced meal based on five food groups and proper meal spacing was not followed by the tribal farm women. Maiti et al., (2005) did a situational analysis of tribal women in Jharkhand and reported the similar findings that tribal women are malnourished and their dietary energy intake is not adequate to compensate their heavy physical workload.
In conclusion, tribal farm women were coming from poor socio-economic background, most of them were illiterate, their income was less and nutritional status was poor. Only half of the tribal farm women were having BMI in acceptable range. Large numbers of tribal farm women were found to be underweight. Their average height, weight and BMI was found lower than reference Indian women. Their food consumption pattern was not appropriate and frequency of consuming nutritious foods i.e. dal, pulses, millets and fruits was less and irregular. Tribal women were malnourished and their diet was not balanced to compensate their heavy physical workload.

\section{References}

Agrawal S. (2013). Disadvantageous situation of tribal women and children of Orissa, India: A special reference to their health and nutritional status. J. Cотти. Nutr. Health, 2(1), 3-14.

Anonymous (2009). Nutrient requirements and recommended dietary allowances for Indians. A report of the expert group of the Indian council of medical research, Published by National Institute of Nutrition, 24. 
Anonymous, http://apps.who.int/bmi/index. jsp?introPage=intro_3.html

Dave P. H., Mistry J. J., Chaudhary M. K., (2016). Assessment of nutritional status of tribal school going children of Sabarkantha district, Gujarat. Int. J. Agri. Sci., 8(51), 2308-2311.

Kupputhai U., Mallika N. (1993). Nutritional status of adult women belonging to Khond, Gadaba and Porja tribes of Andhra Pradesh. Indi. J. Nutr. Diet., 30:173-179.

Maiti S., Unisa S, Agrawal P.K., (2005). Health care and health among tribal women in Jharkhand: A situational analysis. Study Tribe Tribal, 3:37-46.

Rao H. D., Brahmam G. N. V., Rao M. K,
Reddy C. H., Rao P. N. (1996). Nutritional profile of certain Indian Tribes. Proceedings of a national seminar on tribal development options. PK Samal, edt GB Pant. Institute of Himalayan Environment \& Development, Almora, India.

Rao H. D., Rao M. K. (1994). Levels of malnutrition and socio-economic conditions among Maria Gonds. $J$. Hum. Ecol., 5: 185-190.

Rao K.M., Balakrishna N., Laxmaiah A., Venkaiah K., Brahmam G.N.V., (2006). Diet and nutritional status of adolescent tribal population in nine states of India. Asia Pac. J. Clin. Nutr. 15(1): 64-71.

\section{How to cite this article:}

Preeti H. Dave, J.J. Mistry and Chaudhary, M.K. 2019. Nutritional Status and Food Consumption Pattern of Tribal Farm Women of Sabarkantha. Int.J.Curr.Microbiol.App.Sci. 8(03): 2239-2245. doi: https://doi.org/10.20546/ijcmas.2019.803.267 